\title{
Prevalence and determinants of osteoporosis in women aged 40-60 years
}

\author{
Priya A. Vaasanthi, Sreekumary Radha, Bindu Nambisan*
}

Department of Obstetrics and Gynaecology, Medical College, Trivandrum, Kerala, India

Received: 11 October 2016

Accepted: 07 November 2016

\author{
*Correspondence: \\ Dr. Bindu Nambisan, \\ E-mail: bindu.nambisan1971@gmail.com
}

Copyright: ( ) the author(s), publisher and licensee Medip Academy. This is an open-access article distributed under the terms of the Creative Commons Attribution Non-Commercial License, which permits unrestricted non-commercial use, distribution, and reproduction in any medium, provided the original work is properly cited.

\begin{abstract}
Background: Osteoporosis is a global problem which is affecting both the developed and the developing countries and also affecting men and women alike. In our community, it has been affecting adult women at a considerably earlier age than the western counterparts. Increasing life expectancy and a consequent increase in the elderly population has posed a new challenge to their health needs. Fractures related to osteoporosis are quite common. It is also an established fact that bone density measurements correlate well to the risk of developing fracture. This can be measured using DEXA (Dual energy X Ray Absorptiometry) and Quantitative Ultrasound (QUS). It is estimated that 1 out of 8 males and 1 out of 3 females suffer from this, making India one of the highest affected counties in the world.

Methods: This was a cross sectional study done over a period of 12 months at this tertiary care centre in Trivandrum, Kerala. A sample size was calculated statistically and 400 women in this age group were included in this study. A structured proforma and QUS were the study tools. The bone mineral density of the calcaneum on the right foot was measured. The t-score values were obtained using quantitative ultrasound and individuals with the score values less than -2.5 were categorized as osteoporotic.

Results: In this hospital, prevalence of osteoporosis is $17.25 \%$ and findings suggest a significant positive correlation between age, time since menopause, sunlight exposure, family history of osteoporosis and Bone mineral density.

Conclusions: Quantitative ultrasound conclusively confirms or rules out osteoporosis or osteopenia in any population and can be used as a screening tool.
\end{abstract}

Keywords: DEXA, Osteoporosis, QUS

\section{INTRODUCTION}

Osteoporosis is a global problem with a high prevalence in the developed countries and an increasing trend in developing countries owing to increased longevity. ${ }^{1}$ This has posed a new challenge to the health needs and care of elderly. An International consensus development conference has stated that osteoporosis is a systemic skeletal disease characterized by low bone mass and micro-architect deterioration of bone tissue with consequent increase in bone fragility and susceptibility to fractures. $^{2}$
It is characterized by generalized reduction in bone mass due to subnormal osteoid production, excessive rate of de-ossification and sub normal osteoid mineralization. The recent World Health Organization (WHO) criteria, states that osteoporosis is also used to designate a bone mass value more than 2.5 standard deviations (SD) below the young adult mean. ${ }^{3}$ Recent surveys state that osteoporosis is second only to cardiovascular disease as a global health care problem. This slowly progressing metabolic bone disease is widely prevalent in India. It is estimated that by 2050, half of the world's fractures will occur in Asia. ${ }^{4,5}$ Almost one in three urban Indian women past the age of 45 has osteoporosis. Several studies have noted that Indian women suffer from this debility at a 
much younger age than their western counterparts. Fractures related to osteoporosis are common. Statistics show that 1 in 3 women over 45 will suffer a fracture due to osteoporosis; this increases to 1 in 2 over 60 years. ${ }^{6}$ The lifetime risk for an osteoporotic fracture of hip, spine or wrist has been reported to be $40 \%$. Hence necessary steps should be taken to screen the women aged 40 -60 yrs for osteoporotic risk and prevent them from developing osteoporosis at an early age. This reduces the burden of health care system as treatment of osteoporosis is expensive. Globally, the total number of deaths related to hip fracture disease ranges from 20,000 to 30,000 annually. The annual incidence rate of osteoporotic fractures in women is greater than the combined incidence rates of heart attack, stroke and breast cancer. Once a woman suffers a first vertebral fracture, there is a five-fold increase in the risk of developing a new fracture within five years. Apart from fractures, clinical manifestations of osteoporosis includes acute or chronic back pain, loss of height with change in body stature, restricted movement, immobility, dependence on nursing, loneliness, depression, reduced quality of life, and increased mortality. The risk factors for osteoporosis include increasing age, female sex, Asian origin, weight below $58 \mathrm{~kg}$, BMI <25, family history of osteoporosis, family history of hip fracture, sedentary lifestyle, premature ovarian failure, nutritional deficiency of calories, proteins, low calcium intake, excessive consumption of caffeine and alcohol and chronic illness like diabetes, hypertension, ischaemic heart disease, lung diseases, mal-absorption syndrome and breast cancer.

Bone mineral density is the best available means to assess bone strength and the only important tool in the early diagnosis of osteoporosis so that effective preventive and therapeutic measures can be initiated at the earliest. It is acknowledged that bone density measurements were related to future fracture risk. ${ }^{8}$ Several techniques exist for measuring bone mass or density. BMD is calculated using Dual Energy X-ray Absorptiometry (DEXA) and quantitative ultrasound. Quantitative Ultrasound (QUS) is a newer evolving promising technique which is finding increasing application. ${ }^{9}$ Retrospective and prospective studies have shown that QUS may be an alternative or complementary investigation to Dual Energy X-Ray absorptiometry (DEXA). ${ }^{10,11}$ Several prospective studies have reported that ultrasound of the heel was roughly equivalent to DXA in predicting overall fracture risk.

The calcaneus is the most popular measurement site for QUS, as it is easily accessible, and for weight-bearing bone like the neck of femur and the vertebral bodies. Also it consists of almost only metabolically active trabecular bone and may express early skeletal changes. QUS has been used in this study as a screening tool as it is relatively inexpensive, portable and free of ionizing radiation. DEXA has high radiation exposure and not easily portable.

\section{METHODS}

A cross sectional study was conducted at Department of Obstetrics and Gynaecology, SAT Hospital, Medical College, Trivandrum, Kerala, India during period of 12 months.

\section{Sample size}

400 patients has been included in this study in the age group of $40-60$ years using the formula,

$$
n=\frac{4 p q}{l^{2}}
$$

Where, $p=0.5$ (prevalence of disease)

$$
\begin{aligned}
& q=1-\mathrm{p} \\
& l=10 \% \text { of } \mathrm{p}
\end{aligned}
$$

\section{Source of patients}

Patients attending the gynaecology OPD, SAT Hospital, Trivandrum.

\section{Inclusion criteria}

Patients attending gynaecology OPD in the age group of 40-60 yrs.

Patients who are willing to participate.

\section{Exclusion criteria}

Patients with already diagnosed Systemic diseases like renal and hepatic disorders, rheumatoid arthritis, thyrotoxicosis, Addisons disease and Cushings syndrome.

Patients on long term steroids, heparin, warfarin, thyroxine, hydrocortisone, phenytoin, hormone replacement.

Patients who are not willing to participate in the study.

\section{Study tools}

Structured proforma, Quantitative ultrasound

\section{Study procedure}

Patients who reported to the OPD of Gynaecology in the age group of 40-60 yrs were included in the study. Informed consent and a proforma to record the patient's personal and demographic details were obtained. The bone mineral density of the calcaneum on right foot was measured with the patient in sitting position by a trained technician in the OPD using quantitative ultrasound (Figure 1, 2). The $\mathrm{t}$-score values were obtained using 
quantitative ultrasound. Individuals with $\mathrm{t}$ score values less than -2.5 were categorized as osteoporotic. Those with $t$ score between -2.5 and -1 were considered osteopenic and those with values more than -1 were considered to be normal.

\section{RESULTS}

Table 1: Age distribution.

\begin{tabular}{|lll|}
\hline A ge group & Total number of women & Percentage \\
\hline $40-44$ yrs & 141 & 32.25 \\
\hline $45-49$ yrs & 111 & 27.75 \\
\hline $50-54$ yrs & 78 & 19.25 \\
\hline $55-60$ yrs & 70 & 17.75 \\
\hline Total & 400 & 100 \\
\hline
\end{tabular}

\section{Age distribution}

$35.25 \%$ of study sample were in the age group of $40-44$ years, $27.75 \%$ were between $45-49$ years, $19.25 \%$ were between $50-54$ years, $17.75 \%$ women were between 55 60 years.

\section{Educational status}

$9 \%$ were illiterate, $30 \%$ women studied till class $7,42.5 \%$ studied till 10th, $19 \%$ had studied up to degree.

Table 2: Primary outcome.

\begin{tabular}{|llll|}
\hline $\begin{array}{l}\text { Primary } \\
\text { outcome }\end{array}$ & $\begin{array}{l}\text { Number of } \\
\text { women }\end{array}$ & $\begin{array}{l}\text { Prevalence } \\
\text { of disease }\end{array}$ & $\begin{array}{l}95 \% \\
\text { confidence } \\
\text { interval }\end{array}$ \\
\hline $\begin{array}{l}\text { Osteoporosis } \\
69\end{array}$ & $17.25 \%$ & $\begin{array}{l}13.78- \\
21.19 \%\end{array}$ \\
\hline $\begin{array}{l}\text { Osteopenia } \\
\text { Normal }\end{array}$ & \multirow{2}{*}{165} & $41.25 \%$ & $\begin{array}{l}36.50- \\
46.13 \%\end{array}$ \\
\hline BMD & 166 & $41.50 \%$ & $\begin{array}{l}36.74- \\
46.38 \%\end{array}$ \\
\hline
\end{tabular}

\section{Occupation}

$77.25 \%$ of women in our study population were housewives, $9 \%$ were manual labourers, $12 \%$ were having office work and $1.75 \%$ was doing a professional job.

\section{Primary outcome}

In our study $17.25 \%$ of women were osteoporotic, $41.25 \%$ women had osteopenia and $41.5 \%$ of women had normal BMD on QUS.

A comparison between normal and osteoporotic women with respect to age was done and the results were tabulated. Majority of osteoporotic women (36.6\%) in this study were in the age group of $55-60$ yrs. As age increases, the prevalence of osteoporosis also increases.
Mean age of cases is 50.91 and control group is 45.99 and is statistically significant $(\mathrm{p}=0.0001)$.

Table 3: Comparison between normal and osteoporotic women with respect to age.

\begin{tabular}{|lcccl|}
\hline $\begin{array}{l}\text { Age } \\
\text { group }\end{array}$ & Normal & Osteoporosis & $\begin{array}{l}\text { Total } \\
\text { no of } \\
\text { women }\end{array}$ & $\begin{array}{l}\text { Women } \\
\text { with } \\
\text { osteoporosis } \\
(\%)\end{array}$ \\
\hline $\begin{array}{l}40- \\
44\end{array}$ & 80 & 14 & 141 & $9.9 \%$ \\
\hline $\begin{array}{l}45- \\
49\end{array}$ & 42 & 18 & 111 & $16.2 \%$ \\
\hline $\begin{array}{l}50- \\
54\end{array}$ & 28 & 11 & 77 & $14.28 \%$ \\
\hline $\begin{array}{l}55- \\
60\end{array}$ & 16 & 26 & 71 & $36.6 \%$ \\
\hline Mean & 45.99 & 50.91 & & \\
\hline SD & 5.36 & 6.69 & & \\
\hline
\end{tabular}

$\mathrm{t}$ value $=-5.430 ; \mathrm{p}$ value $=0.0001$

\section{Distribution according to age of menarche}

Mean age at menarche for osteoporotic women was 13.75 and that of normal women was 13.69 in this study and did not show statistical significance.

Table 4: Distribution according to menopausal status.

\begin{tabular}{|lccccc|}
\hline \multicolumn{7}{c}{ Osteoporosis } & Normal & total \\
\hline $\begin{array}{l}\text { Menopause } \\
\text { attained }\end{array}$ & 38 & $55 \%$ & 50 & $30.1 \%$ & 88 \\
\hline $\begin{array}{l}\text { Menopause } \\
\text { not attained }\end{array}$ & 31 & $44.9 \%$ & 116 & $69.8 \%$ & 147 \\
\hline Total & 69 & & 166 & & 235 \\
\hline $\begin{array}{l}\text { Chi-square } \\
\text { value }=12.9\end{array}$ & Odds ratio =2.84 & & \\
\hline $\begin{array}{l}\text { p value }= \\
0.00032\end{array}$ & $95 \% \mathrm{CI}=1.53$ & -5.29 & & \\
\hline
\end{tabular}

\section{Distribution according to menopausal status}

Relationship between menopause and osteoporosis was checked and in our study, 55\% of women who had osteoporosis were postmenopausal, when compared to only $30.1 \%$ of normal women had attained menopause. Menopausal status was statistically significant in this study. $(\mathrm{p}$ value $=0.00032)$.

\section{Distribution according to age since menopause}

In this study, $39.4 \%$ of osteoporotic women had menopausal age of $<5$ years and $23.6 \%$ had menopausal age $>10$ years. Mean duration of menopause was $7.61 \mathrm{yrs}$ in cases and 5.43 yrs in control group ( $p$ value $=0.032$ ). According to this, years since menopause, shows statistical significance. 
Table 5: Distribution according to age since menopause.

\begin{tabular}{|lll|}
\hline $\begin{array}{l}\text { Age since } \\
\text { menopause }\end{array}$ & Osteoporosis & Normal \\
\hline$\leq 5$ yrs & $15(39.4 \%)$ & $33(66 \%)$ \\
\hline $6-10 y r s$ & $14(36.8 \%)$ & $8(16 \%)$ \\
\hline$>10$ yrs & $9(23.6 \%)$ & $9(18 \%)$ \\
\hline Total & 38 & 50 \\
\hline Mean in years & 7.61 & 5.43 \\
\hline SD & 5.28 & 5.48 \\
\hline $\begin{array}{l}\text { Chi-square value } \\
=6.88\end{array}$ & p value: 0.032 & \\
\hline
\end{tabular}

Distribution according to years since last child birth (LCB) for parous women

Mean duration since last child birth was 21.5 years in the cases and 18years in control group ( $\mathrm{p}$ value $=0.0001$ ). According to this study, years since last child birth had significant correlation with osteoporosis.

Table 6: Distribution according to years since last child birth (LCB) for parous women.

\begin{tabular}{|c|c|c|}
\hline & Osteoporosis & Norma \\
\hline $\begin{array}{l}\text { No of parous } \\
\text { women }\end{array}$ & 68 & 161 \\
\hline Mean (years) & 22.63 & 19.06 \\
\hline Median (years) & 21.5 & 18.00 \\
\hline SD & 5.99 & 5.09 \\
\hline
\end{tabular}

p value: 0.0001

\section{Distribution according to menstrual cycle}

In this study, $17.3 \%$ of women with osteoporosis had irregular cycles and $18.6 \%$ of normal women had irregular cycles. Regularity of menstrual cycle did not show statistical significance here.

Table 7: Distribution according to calorie intake in 24 hr recall.

\begin{tabular}{|lll|}
\hline No of women & 69 & Osteoporosis \\
\hline $\begin{array}{l}\text { Mean calorie intake } \\
\text { (kcal) }\end{array}$ & 1456 & 166 \\
\hline SD & 238 & 1491.5 \\
\hline
\end{tabular}

t test : $0.967 ; p$ value: 0.335

\section{Distribution according to marital status}

69 women diagnosed with osteoporosis were married, 163 women amongst those with normal BMD were married and 3 were unmarried. According to Fisher's Exact test, $\mathrm{p}$ value $=0.56$. Marital status did not show significant correlation with osteoporosis.
Table 8: Distribution according to calorie intake in 24 hr recall.

\begin{tabular}{|lll|}
\hline & Osteoporosis & Normal \\
\hline No of women & 69 & 166 \\
\hline Mean in grams & 51.49 & 48.85 \\
\hline SD & 14.86 & 13.97 \\
\hline
\end{tabular}

t test: -1.26 ; $p$ value: 0.209

\section{Distribution according to calorie intake in $24 \mathrm{hr}$ recall}

According to this, mean calorie intake for case was 1456 $\mathrm{k}$ cal and that of control was $1491.5 \mathrm{k}$ cal and did not have significant correlation with osteoporosis.

\section{Distribution according to protein intake in $24 \mathrm{hr}$ recall}

Mean protein intake for cases was 51.49 grams and that of control was 48.85 grams. Protein intake did not show significant correlation with osteoporosis in this study (Table 8).

Table 9: Distribution according to calcium intake/24 hr recall.

\begin{tabular}{|lll|}
\hline & Osteoporosis & Normal \\
\hline No of women & 69 & 166 \\
\hline $\begin{array}{l}\text { Mean calcium intake } \\
\text { (gms) }\end{array}$ & 367.7 & 391.02 \\
\hline SD & 140.85 & 139.36 \\
\hline
\end{tabular}

t test: $1.161 ; \mathrm{p}$ value: 0.248

Table 10: Distribution according to family history of osteoporosis.

\begin{tabular}{|lll|}
\hline Family h/o & Osteoporosis & Normal \\
\hline present & $16(23.1 \%)$ & $17(10.2 \%)$ \\
\hline absent & $53(76.8 \%)$ & $149(89.7 \%)$ \\
\hline Total & 69 & 166 \\
\hline $\begin{array}{l}\text { Chi-square value } \\
=6.77\end{array}$ & p value $=0.0093$ & \\
\hline Odds ratio $=2.6595 \% \mathrm{CI}=1.17-5.98$ \\
\hline
\end{tabular}

\section{Distribution according to calcium intake/24 hr recall}

Mean calcium intake for cases was 367.7 grams and that of control was 391.02 grams. Calcium intake did not show significant correlation with osteoporosis. $(\mathrm{p}$ value $=$ 0.248). It was also noted in this study that $5.7 \%$ of osteoporotic and $5.4 \%$ of normal BMD women had calcium supplements. Intake of supplements did not show any statistical significance.

\section{Distribution according to exercise}

In this study, $39 \%$ of osteoporotic women had exercise and $45.1 \%$ of normal women had exercise. Exercise does 
not show statistical significance. Also it was noted that duration of exercise was also not statistically significant.

\section{Distribution according to sun exposure}

In this study, $42 \%$ of osteoporotic women had sun exposure where as $58.4 \%$ of normal women had sun exposure. Sun exposure has significant correlation with osteoporosis ( $\mathrm{p}$ value $=0.02$ ) mean duration of sun exposure per day in osteoporotic women is $0.629 \mathrm{hrs}$ and that of normal women is $0.91 \mathrm{hrs}$. According to MannWhitney $\mathrm{U}=1118.5 .0 \mathrm{p}$ value $=0.063$. Here duration of sun exposure had no significant correlation with osteoporosis.

Table 11: Distribution according to presence of diabetes mellitus.

\begin{tabular}{|llllll|}
\hline Diabetes & \multicolumn{2}{l}{ Osteoporosis } & \multicolumn{2}{l|}{ Normal } & Total \\
\hline Yes & 19 & $27.5 \%$ & 19 & $11.4 \%$ & 38 \\
\hline No & 50 & $72.4 \%$ & 147 & $88.5 \%$ & 197 \\
\hline Total & 69 & \multicolumn{5}{c|}{166} \\
\hline Chi- square value $=9.31$ p value=0.0023 \\
\hline \multicolumn{7}{|l}{ Odds ratio $=2.94$} & $95 \%$ & Confidence interval= 1.36 & -6.36 \\
\hline
\end{tabular}

\section{Distribution according to passive smoking}

In this study, $16.1 \%$ of women with osteoporosis had passive smoking and $18.07 \%$ of normal women had passive smoking and did not show statistical significance.

\section{Distribution according to alcohol intake}

None of the women in this study were alcohol users.

Table 12: Distribution according to hypertension.

\begin{tabular}{|c|c|c|c|c|}
\hline Hypertension & Osteoporosis & Norn & & Total \\
\hline Yes & $14.4 \%$ & 20 & $12 \%$ & 30 \\
\hline No & $85.5 \%$ & 146 & $87.9 \%$ & 205 \\
\hline Total & 69 & 166 & & \\
\hline \multicolumn{5}{|c|}{$\begin{array}{l}\text { Chi-square test value }=0.26 \mathrm{p} \text { value }: 0.61 \text { (not } \\
\text { significant) }\end{array}$} \\
\hline Odds ratio $=1$ & $95 \% \mathrm{CI}=0$ & -2.99 & & \\
\hline
\end{tabular}

\section{Distribution according to family history of osteoporosis}

In this study $23.1 \%$ of osteoporotic women had family history of osteoporosis where as $10.2 \%$ of normal women had family history of osteoporosis. Family history has significant correlation with osteoporosis ( $p$ value $=0.0093) .1 .4 \%$ of osteoporotic women had history of fracture above 50 years and $0.6 \%$ of normal women had history of fracture. History of fracture above 50 years did not show any statistical significance ( $\mathrm{p}$ value $=0.52$ ).

\section{Presence of psychological stress}

Over last 3 months did not show any statistical significance in this study with osteoporosis

\section{Distribution according to presence of diabetes mellitus}

$27.5 \%$ of osteoporotic women had diabetes mellitus and $11.4 \%$ of normal women had diabetes. Diabetes had significant correlation with osteoporosis ( $\mathrm{p}$ value $=$ $0.0023)$.

\section{Distribution according to hypertension}

$14.4 \%$ of osteoporotic women had hypertension and $12 \%$ of normal women had hypertension. Hypertension did not show statistical significance $(\mathrm{p}$ value $=0.61)$.

Other co-morbidities like presence of ischaemic heart disease, chronic lung disease etc also did not show any statistical significance. None of the women in this study had breast cancer, skin lesions or malabsorption syndrome.

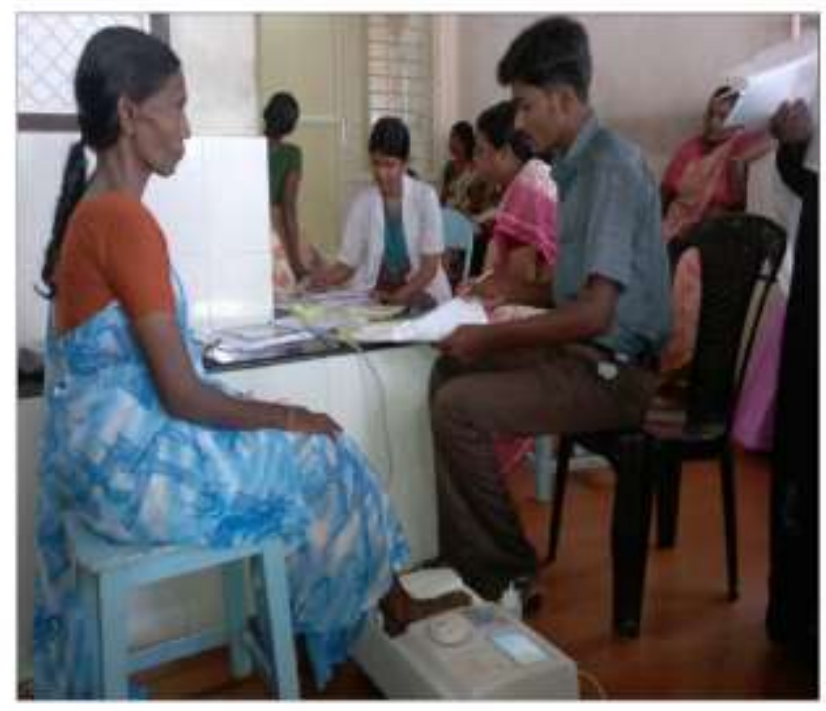

Figure 1: Measurement of BMD by trained technician under supervision of first author.

\section{Distribution according to BMI}

Mean BMI for osteoporotic women was 27.17 and that of normal women was 26.86. BMI did not show significant correlation with osteoporosis.

\section{Anthropometric measurements}

Mid-arm circumference, waist circumference and hip circumference did not show significant correlation with osteoporosis. 


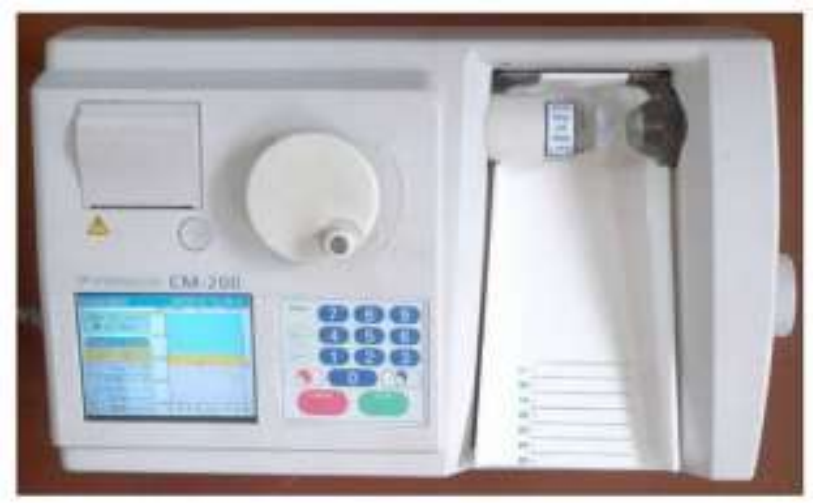

Figure 2: Quantitative ultrasound used in the study.

\section{DISCUSSION}

Of the total of 400 patients involved in this study, majority were in the age group of 40-49 years. This could be the reason why a low prevalence was noted compared to previous studies. The prevalence of osteoporosis was $17.25 \%$ and that of osteopenia was about $41.5 \%$ which indicates that rates could rise further in coming years. The prevalence of osteopenia was $59.3 \%$ in women of age group 40-49 yrs and it is established that osteoporosis rises steeply after 50 yrs. There was a statistically significant rise in older age group $(\mathrm{p}=0.0001)$. Both postmenopausal state, as well as years since menopause showed statistical significance .Though age of menarche, regularity of menstrual cycle and marital status did not reveal statistical significance, years since last childbirth, had a significant correlation $(\mathrm{p}=0.0001)$ The calcium intake of our study population was only $350 \pm 50 \mathrm{mg} /$ day as compared to the RDA of $800-1,000 \mathrm{mg} /$ day, which is accepted worldwide. However, the RDA for calcium has not been established for menopausal women in India subsisting on a cereal-pulse diet, and therefore 400 $\mathrm{mg}$ /day of RDA for calcium is indicated. ${ }^{12}$ The major part of this calcium intake came from plant sources, which are known to have low bioavailability. The foods rich in calcium such as milk, spices and dry fruits are expensive and not well available for majority of this population. The intake of other nutrients except fats was also substantially low, resulting in multiple nutrient deficiencies. Nutritional factors like calorie, protein, calcium intake of women involved in this study does not show significant correlation with osteoporosis. Intake of calcium supplements also does not show statistical significance. This may be because all the women studied, were from low socioeconomic group with inadequate dietary intake. History of sunlight exposure is statistically significant ( $p$ value-0.0216) though duration was not. Exercise and passive smoking did not have statistical significance. Presence of diabetes has significant correlation with osteoporosis. $(\mathrm{P}$ value $=0.0023) .{ }^{13}$ Other chronic illnesses like hypertension, ischaemic heart disease, chronic lung disease, did not show statistical significance. Anthropometric measurements and BMI did not show statistical significance.

\section{Quantitative ultrasound}

Identifying women with osteoporosis remains a clinical challenge. Although the results of present study in comparison to the various studies[14,15]clearly reflect the under diagnosis of osteoporosis by QUS in comparison to DEXA, but QUS still remain the commonest modality of measuring bone density of cancellous bone (peripheral bone measurement) in the heel, with advantage of low cost, lack of radiation and portability. Hence, DEXA, remains the gold standard for measuring bone density but underscoring fairly good number of women to be osteopenic and osteoporotic in present study suggest that USG method can be useful particularly in situation where DEXA is not available, who otherwise will remain totally undiagnosed. The incidence indicated in the present study may not be the true incidence of the population as QUS yield a lower incidence or prevalence of osteoporosis if the same WHO $\mathrm{t}$-score is applied.

\section{CONCLUSION}

In this hospital, prevalence of osteoporosis is $17.25 \%$ and findings suggest a significant positive correlation between age, time since menopause, sunlight exposure, family history of osteoporosis and BMD. Differences in the prevalence of osteoporosis exist on the basis of socioeconomic strata. The results of this study did not reveal a statistically significant difference in BMD for many of the other accepted risk factors such as age at menarche, regularity of menstrual cycle, exercise, nutritional factors and smoking. It appears that more studies with larger numbers may be needed to establish their role. The International Osteoporosis Foundation suggests screening of women after age of 65 years. However, changing life style in young people (dieting, smoking, and lack of exercise) has made them vulnerable to osteoporosis at an earlier age. Further in India, there is a higher prevalence of other risk factors such as low socioeconomic strata, low calcium in the diet, Vitamin D deficiency, low education level, premature menopause, multiparty, resulting in higher risk for osteopenia and osteoporosis. Quantitative Ultrasound conclusively confirms or rules out osteoporosis or osteopenia in any population and can be used as a screening tool.

This is a hospital based study, with maximum number of women $(35.25 \%)$ in the age group of $40-44$ yrs and hence prevalence of osteoporosis is lower than the previous studies. Community based studies will detect more number of osteoporotic women when compared to hospital based studies. More studies with large numbers are required to establish the previously accepted risk factors which were not significant in this study.

\section{ACKNOWLEDGEMENTS}

We express our gratitude to Dr. Nirmala C, Professor and HOD, Obstetrics and Gynaecology, Medical College, 
Trivandrum for her masterly guidance in improving the quality of this study. We are also thankful to Shri. Muralidharan Nair S., for carrying out the statistical studies. We are also grateful to Smt Elizabeth Thomas, Senior grade dietician Medical College Trivandrum for providing guidance in nutritional assessment required as a part of this study.

Funding: No funding sources

Conflict of interest: None declared

Ethical approval: The study was approved by the Institutional Ethics Committee

\section{REFERENCES}

1. International Osteoporosis Foundation and National Osteoporosis Foundation white Osteoporosis International. 1999;10:259-64.

2. Consensus Development Conference. Diagnosis, prophylaxis and treatment of osteoporosis. Am J Med. 1993;94:646-50.

3. Endocrinology and Metabolism Clinics of North America. 1998;27(2):255-65.

4. Osteoporosis International. 204;15(211):897-902. Ann Intern. pp. 355- 366.

5. Cooper C, Campion G, Melton LJ III. Hip fractures in the elderly: a world-wide projection. Osteoporos Int. 1992;2:285-9.

6. Osteoporosis Australia Available from: http://www.osteoporosis.org.aug 2004.

7. Riggs BL, Melton LJ. American Heart Association, Heart \& Stroke Facts 1996; American Cancer
Society, Cancer Facts and Figures, 1996. 1995; 17(s5):505S.

8. Hui SL, Slemenda CW, Johnston CC. Baseline measurement of bone mass predicts fracture in Med. 1999.

9. F. Hartl M.D, A. Tyndall, M. Kraenzlin, C. Bachmeier et al, Discriminative ability of quantitative ultrasound parameters and BMD, FEB 2002, 10.1359/jbmr.2002.17.2.321

10. Gregg EW. The epidemiology of quantitative ultrasound: A review of the relationships with bone mass, osteoporosis and fracture risk. Osteoporos Int. 1997;7:89-99.

11. Njeh CF, Boivin CM, Langton CM. The role of ultrasound in the assessment of osteoporosis: A review. Osteoporos Int. 1997;7:7-22t.

12. Shatrugna V, Kulkarni B. Bone status of Indian women from a low-income group and its relationship to the nutritional status Osteoporos Int. 2005; 16:1827-35.

13. Inzerillo AM, Epstein S. Osteoporosis and Diabetes. Mellitus Reviews in Endocrine and Metabolic Disorders. 2004;5(3):261-8.

14. Sallin U, Mellstrom D, Eggertsen R. Osteoporosis in a nursing home, determined by the DEXA technique. Med Sci Monit. 2005;11:CR67-70.

15. Pande KC. Prevalence of low bone mass in healthy Indian population. J Indian Med Assoc 2002;100:598-600-2.

Cite this article as: Vaasanthi PA, Sreekumary R, Nambisan B. Prevalence and determinants of osteoporosis in women aged 40-60 years. Int J Reprod Contracept Obstet Gynecol 2016;5:4434-40. 